

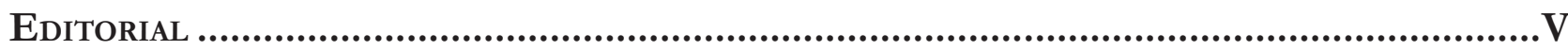

Carlos Ayres Britto, Lilian Rose Lemos Soares Nunes e Marcelo Dias Varella

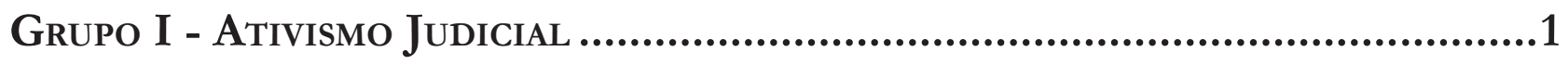

APONTAMENTOS PARA UM DEBATE SOBRE O ATIVISMO JUdiCIAL ................................................ 3 Inocêncio Mártires Coelho

A razão sem voto: o Supremo Tribunal Federal e o governo da maioria......................24 Luís Roberto Barroso

O PROBLEMA DO ATIVISMO JUDICIAL: UMA ANÁLISE DO CASO MS3326 ......................................52 Lenio Luiz Streck, Clarissa Tassinari e Adriano Obach Lepper

Do ativismo Judicial aO ATIVISMO CONSTITUCIONAL No Estado DE DIREITOS FUNDAMENTAIS..... 63 Christine Oliveira Peter

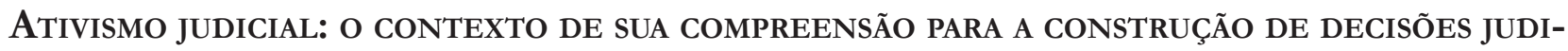
CIAIS RACIONAIS

Ciro di Benatti Galvão

HeRMENÊUTICA FILOSÓFICA E ATIVIDADE JUDICIAL PRAGMÁtICA: APROXIMAÇÕES 101 Humberto Fernandes de Moura

O PAPEL DOS PRECEDENTES PARA O CONTROLE DO ATIVISMO JUDICIAL NO CONTEXTO PÓS-POSITI-

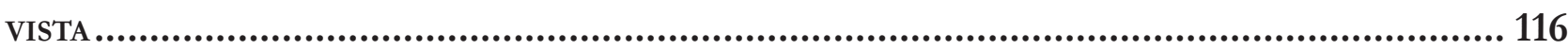
Lara Bonemer Azevedo da Rocha, Claudia Maria Barbosa

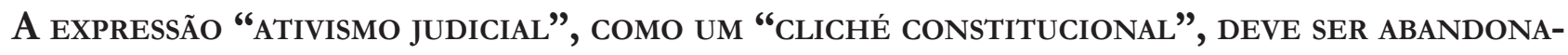
DA: UMA ANÁLISE CRÍTICA 135 Thiago Aguiar Pádua

A atuação do Supremo Tribunal Federal frente aos fenômenos da judicialização da POLÍTICA E DO ATIVISMO JUDICIAL 170

Mariana Oliveira de Sá e Vinícius Silva Bonfim 
Ativismo judicial e democracia: a ATUaÇão do STF E o EXercício da Cidadania no Brasil..191 Marilha Gabriela Reverendo Garau, Juliana Pessoa Mulatinho e Ana Beatriz Oliveira Reis

Grupo II - Ativismo Judicial e Políticas Públicas...................................207

Políticas Públicas E ATIVISMO JUdiCial: O DILEMa ENTRE EFETIVIDAde E LIMITES DE ATUAÇÃo............209 Ana Luisa Tarter Nunes, Nilton Carlos Coutinho e Rafael José Nadim de Lazari

Controle Judicial das Políticas Públicas: Perspectiva da hermenêutica filosófica e

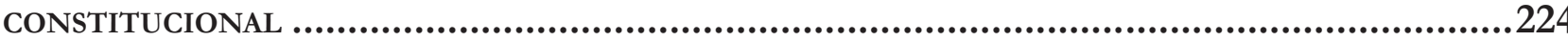

Selma Leite do Nascimento Sauerbronn de Souza

A atUAÇão do PODER JUdiciário NO ESTADO CONSTITUCIONAL EM FACE DO FENÔMENO DA JUDI-

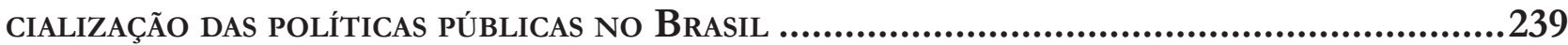

Sílvio Dagoberto Orsatto

Políticas PÚblicas E PROCESSO ELEITORAL: REFLEXÃo A PARTIR DA DEMOCRACIA COMO PROJETO POLÍTICO

Antonio Henrique Graciano Suxberger

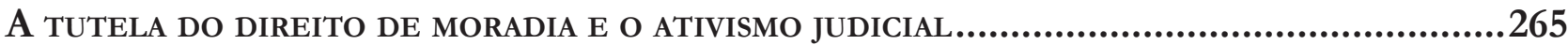

Paulo Afonso Cavichioli Carmona

Ativismo Judicial e Direito à Saúde: a judicialização das políticas públicas de saúde e os impactos da POStura ativista do Poder Judiciário.

Fernanda Tercetti Nunes Pereira

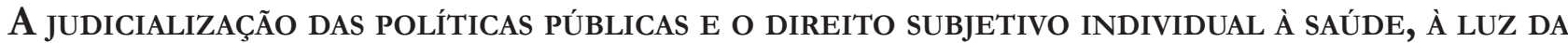
TEORIA DA JUSTIÇA DISTRIBUTIVA DE JoHN RAWLS

Urá Lobato Martins

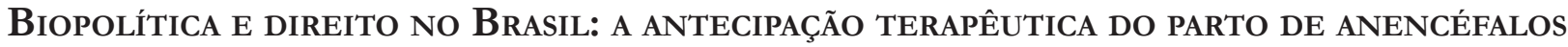
COMO PROCEDIMENTO DE NORMALIZAÇÃO DA VIDA

Paulo Germano Barrozo de Albuquerque e Ranulpho Rêgo Muraro

Ativismo judicial e judicialização da política da RelaÇão de Consumo: uma análise do CONTROLE JURISDicional dos CONTRATOS DE PLANOS DE SAÚDE PRIVAdo No ESTADo DE São

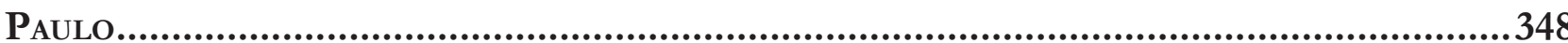
Renan Posella Mandarino e Marisa Helena D’Arbo Alves de Freitas 
A atuaÇão do Poder Judiciário na implementaÇão de políticas públicas: o caso da deMARCAÇÃO DOS TERRITÓRIOS QUILOMBOLAS ........................................................362 Larissa Ribeiro da Cruz Godoy

Políticas públicas e etNodesenVolvimento com ENFOQUe NA LEGISLAÇão INDigenista BRASILEIRA

Fábio Campelo Conrado de Holanda

Tentativas de contenção do ativismo judicial da Corte Interamericana de Direitos Humanos

Alice Rocha da Silva e Andrea de Quadros Dantas Echeverria

O desenvolvimento da Corte Interamericana de Direitos Humanos. .410 André Pires Gontijo

O ATivismo judicial da Corte Europeia de Justiça para alÉm da integração europeia...... 425 Giovana Maria Frisso

Grupo III - Ativismo Judicial e Democracia.....

Liberdade de Expressão e Democracia. Realidade intercambiante e necessidade de aprofundamento da Questão. Estudo comparativo. A jurisprudênCia do Supremo Tribunal Federal no Brasil- Adpf 130- e a Suprema Corte dos Estados Unidos da AmériCA.

Luís Inácio Lucena Adams

A germanística JuRídica e a metáfora do dedo EM Riste no CONTEXTO EXPLORATIVO das JUSTIFICATIVAS DA DOGMÁTICA DOS DIREITOS FUNDAMENTAIS

Arnaldo Sampaio de Moraes Godoy

Anarquismo Judicial e Segurança Jurídica Ivo Teixeira Gico Jr.

A (DES)hARMONIA ENTRE OS PODERES E O DiÁlOgo (IN)TENSO ENTRE DEMOCRACIA E REPÚBLI-

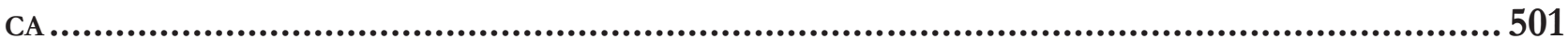

Aléssia de Barros Chevitarese

Promessas da modernidade e Ativismo Judicial. 519 Leonardo Zehuri Tovar

Por DENTRO DAS SUPREMAS CORTES: BASTIDORES, TELEVISIONAMENTO E A MAGIA DA TRIBUNA..... 538 Saul Tourinho Leal 
Direito Processual de grupos Sociais no Brasil: UMA VERsão REVISTA E ATUALIZADA DAS PRIMEIRAS LINHAS

Jefferson Carús Guedes

A OUTRA REALIDADE: O PANCONSTITUCIONALISMO NOS Isteites .

Thiago Aguiar de Pádua, Fábio Luiz Bragança Ferreira E Ana Carolina Borges de Oliveira

A resolução n. 23.389/2013 do Tribunal Superior Eleitoral E a tensão entre os podeRES CONSTITUÍDOS

Bernardo Silva de Seixas e Roberta Kelly Silva Souza

O RESTABELECIMENTO DO EXAME CRIMINOLÓGICO POR MEIO DA SÚMULA VINCULANTE $\mathrm{N}^{\circ}$ 26:

UMA MANIFESTAÇÃO DO ATIVISMO JUDICIAL .....................................................6 622

Flávia Ávila Penido e Jordânia Cláudia de Oliveira Gonçalves

Normas Editoriais .................................................................................6 637

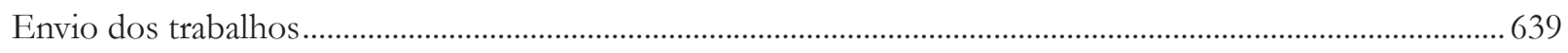




\section{A atuação do Supremo Tribunal Federal frente aos fenômenos da judicialização da política e do ativismo judicial*}

\section{The procedure of the Supreme Court front the phenomena of judicialization of politics and of judicial activism}

\author{
Mariana Oliveira de Sá** \\ Vinícius Silva Bonfim***
}

* Recebido em 30/10/2014 Aprovado em 17/01/2015

** Graduanda em Direito pela Faculdade Arquidiocesana de Curvelo. Monitora das disciplinas Teoria Geral do Direito e Direito Civil da Faculdade Arquidiocesana de Curvelo. Estagiária do Ministério Público de Minas Gerais. E-mail: marianaoliveiradesa@yahoo.com

*** Mestre e Doutor em Teoria do Direito pelo Programa de Pós-Graduação em Direito da Pontifícia Universidade Católica de Minas Gerais - PPGD - PUCMINAS. Professor de Direito Constitucional, Teoria do Estado e Ciência Política na Faculdade Arquidiocesana de Curvelo (FAC). E-mail: bonfimbh@hotmail. com

\section{Resumo}

Este trabalho tem como objetivo estudar a atuação do Supremo Tribunal Federal (STF) no que se refere aos fenômenos da judicialização da política e do ativismo judicial, ambos estão em destaque no cenário da jurisdição constitucional brasileira e possuem sutis diferenças que possibilitam grandes distinções. Utilizou-se como metodologia estudo bibliográfico da teoria do direito como integridade de Ronald Dworkin, além de análise da jurisprudência do STF. Faz-se uma apresentação das diferenças existentes entre os dois fenômenos para que se torne possível saber quando o STF está atuando legitimamente na efetividade de direitos e quando ele ultrapassa sua competência constitucional, agindo, portanto, de forma discricionária. Desse modo, chegou-se à conclusão de que a linha é tênue entre a judicialização da política e o ativismo judicial. A teoria do direito, como integridade de Ronald Dworkin, que subsidiou a pesquisa, possibilita a construção de alicerce de princípios que estrutura e fundamenta as raízes de uma democracia constitucional. Assim, o artigo além de realizar as distinções entre ambos os fenômenos, traz também alguns casos práticos que contribuem para melhor esclarecimento da distinção entre diretriz política e princípios de direito. Trata-se de trabalho de grande relevância para o contexto jurídico atual, e de originalidade na forma da distinção realizada entre o ativismo judicial e a judicialização da política.

Palavras-chave: Supremo Tribunal Federal. Jurisdição Constitucional. Judicialização da Política. Ativismo Judicial. Democracia.

\section{Abstract}

This work aims to study the role of the Supreme Court (STF) in relation to the phenomena of judicialization of politics and judicial activism, both are featured in the scenario of Brazilian constitutional jurisdiction and have subtle differences that enable large distinctions. Was used as a bibliographic study methodology of the theory of law as integrity of Ronald Dworkin, and analysis of the Supreme Court jurisprudence. It will be a presentation 
of the differences between the two phenomena so that it becomes possible to know when the Supreme Court is acting legitimately in the effectiveness of rights and when it exceeds its constitutional authority, acting therefore a discretionary basis. Thus, we come to the conclusion that the line is blurred between the judicialization of politics and judicial activism. The theory of law as integrity of Ronald Dworkin which supported the research, allows the construction of a foundation of principles that structure and founded the roots of a constitutional democracy. So, Article besides carrying out the distinctions between the two phenomena, it also brings some practical cases that contribute to better understanding of the distinction between policy guidelines and principles of law. This is of great relevance to the current legal environment work, and originality in the form of the distinction made between judicial activism and the judicialization of politics.

Keywords: Supreme Court. Constitutional Jurisdiction. Judicialization of Politics. Judicial Activism. Democracy.

\section{INTRODUÇÃO}

A República Federativa do Brasil se constitui em um Estado Democrático de Direito, fundado no instituto da separação dos poderes: Executivo, Legislativo e Judiciário, que são independentes e harmônicos entre si. Mas, em cada momento histórico, pode-se diagnosticar uma atuação mais enfática de cada um deles. Exemplo disso foi o destaque dado ao legislativo nos séculos XVII e XVIII na Inglaterra, seja com o Bill of Rights ou até mesmo com a ideia utilitária, disseminada por Bentham, de que o legislativo teria primeiramente, a função de maximizar o bem estar da sociedade. ${ }^{1}$

No início do século XX, com o predomínio de políticas sociais, adotadas pelo fracasso da política liberal, o Poder Executivo ganhou destaque. No Brasil teve-se exemplos claros como Getúlio Vargas e Juscelino Kubistchek. Mas a centralização no executivo ficou ainda mais notória quando passou a ser arbitrária, ditatorial, entre 1964-1984.

Em pleno século XXI, o Poder Judiciário surge como protagonista, uma vez que se tornou vulgarmente como o guardião da Constituição, portanto, da democracia.

É nesse sentido que surge a necessidade de estudar a atuação do Poder Judiciário, mais especificamente, do Supremo Tribunal Federal, a partir da finalidade de verificar se a instituição está atuando a partir de critérios de legitimidade e quais sãos os parâmetros estabelecidos para os limites dessa atuação que tem como escopo aplicar os direitos e garantias fundamentais.

Atualmente estão em destaque os fenômenos da judicialização da política e do ativismo judicial. Vários são os motivos que contribuem para essa realidade, mas dentre eles, pode ser destacado como o principal o princípio da inafastabilidade da jurisdição, consagrado no art. $5^{\circ}$, inciso XXXV, da Constituição da República de 1988. Isto é, não pode o Poder Judiciário se abster de decidir uma demanda quando provocado.

Nesse contexto o objetivo deste estudo consiste em analisar os dois fenômenos principais que estão na pauta da jurisdição constitucional: a judicialização da política e o ativismo judicial.

Embora esses fenômenos sejam amplamente divulgados na contemporaneidade pela literatura jurídica, muitas vezes são citados como sinônimos. A grande maioria dos autores não distinguem judicialização da política e ativismo judicial, não apresentam as possíveis diferenças entre julgar politicamente e julgar problemas que são afins à política.

Nesse sentido, para a realização desta pesquisa, utilizou-se como metodologia o estudo bibliográfico das principais obras que tratam sobre o tema e análise da jurisprudência do STF. É notório que a intensa atua-

1 Para saber mais: BENTHAM, Jeremy. Uma introdução aos princípios da moral e da legislação. São Paulo: Nova Cultura, 1989. 
ção do Poder Judiciário na contemporaneidade é marcada pelo aumento do acesso ao judiciário. ${ }^{2}$ Mas saber quando o STF está atuando legitimamente na efetividade de direitos e quando ele ultrapassa sua competência constitucional, agindo de forma discricionária, é o objetivo desse artigo. Essa questão será abordada a seguir, logo após breve explanação da teoria do direito como integridade de Ronald Dworkin.

\section{A leitura de Ronald Dworkin para a compreensão da legitimidade da Justificação CONSTITUCIONAL}

Compreender o ramo do direito e o conceito de política consiste em questão complexa e delicada, principalmente quando características de ambos os fenômenos sociais se misturam em um só problema: a efetividade dos direitos fundamentais.

Ronald Dworkin é, sem dúvida, uma das maiores autoridades no que tange à teoria da decisão. Em suas obras, o autor apresenta o cerne do problema de toda a teoria do direito: saber o que é o direito. ${ }^{3}$

O autor afirma que "vivemos na lei e segundo o direito", e nesse sentido, Pedron considera que,

O Direito está por todo lado na vida em sociedade, fazendo-se presente desde antes do nascimento e estendendo-se até após a morte de um indivíduo. É o Direito que estabelece a condição de cidadão, de empregado ou de empregador, de advogados, de proprietários, de cônjuge, de sócio etc. O Direito não é apenas algo restrito ao ambiente formal dos tribunais, mas transborda para além de suas construções. Ele apresenta-se como um soberano abstrato dotado, simultaneamente, de um escudo e de uma espada ${ }^{5}$.

Dworkin busca superar em sua teoria a tradição do direito natural e o positivismo jurídico. Ele reconhece a existência em prol dos indivíduos, de outros direitos além daqueles criados explicitamente pela legislação, pelos costumes ou pelo precedente judicial: são direitos cuja fonte reside em outras pautas de regulação de conduta, ainda que se trate de um caso controverso e que podem decorrer dos princípios ou das políticas públicas.

Assim, o filósofo trabalha o direito como um fenômeno interpretativo e estabelece três etapas de interpretação para que a interpretação construtiva seja o mecanismo apropriado ao estudo do direito enquanto prática social:

Primeiro, de acordo com Dworkin, deve haver uma etapa pré-interpretativa, na qual são identificados as regras e os padrões que se considerem fornecer o conteúdo experimental da prática. Mesmo na etapa pré-interpretativa é necessário algum tipo de interpretação. Em segundo lugar, deve haver uma etapa interpretativa em que o intérprete se concentra numa justificativa geral para os principais elementos da prática identificada na pré-interpretativa. Isso vai consistir numa argumentação sobre a conveniência ou não de buscar uma prática com essa forma geral, raciocinar no sentido de buscar formar um pensamento sistemático sobre determinada matéria. A etapa pós-interpretativa ou reformuladora, a terceira e última etapa, consiste na etapa na qual o intérprete ajusta sua ideia daquilo que a prática "realmente" requer para melhor servir à justificativa que ele aceita na etapa interpretativa ${ }^{6}$.

\footnotetext{
2 Compreende-se, neste estudo, que a judicialização da política não se confunde com acesso à justiça, portanto, utiliza-se o termo acesso ao judiciário para fazer essa distinção entre os dois termos acima citados, uma vez que o simples acesso ao judiciário não garante o devido processo constitucional.

3 Esse questionamento é a essência do debate entre Hart e Dworkin, entre o positivismo e o pós-positivismo. Para saber mais: O modelo de regras I em: DWORKIN, Ronald. Levando os direitos a sério. São Paulo: M. Fontes, 2002. e HART, H. L. A. et al. O conceito de direito. São Paulo: WMF M. Fontes, 2009.

4 DWORKIN, Ronald. O império do direito. Trad. Jefferson Luiz Camargo. 2. ed. São Paulo: M. Fontes, 2007.

5 PEDRON, Flávio Quinaud. A proposta de Ronald Dworkin para uma interpretação construtiva do direito. Revista CEJ, Brasília, Ano XIII, n. 47, p. 127-137, out./dez. 2009. p. 128.

6 LAGES, Cíntia Garabini. A proposta de Ronald Dworkin em o império do direito. Revista da Faculdade Mineira de Direito, Belo Horizonte, v. 4, n. 7/8, p. 40, jan./jun., 2001.
} 
O direito para Dworkin pressupõe dinamismo e permanente transformação, sem deixar de ser coerente, em virtude de ele compreendê-lo como integridade. A integridade, no domínio da legislação, é princípio político, que exige que as normas elaboradas pelos legisladores sejam moralmente coerentes, enquanto que, relativamente às decisões judiciais, exige dos juízes que o direito seja moralmente coerente, pelo que devem construir argumentos de forma integrada ao conjunto do ordenamento em vigor.

Para o autor, não basta que as instituições sociais sejam guiadas pelos ideais de equanimidade (fairness), justiça e devido processo legal (procedure due process), é necessário se ter presente a integridade. Ele sustenta que,

A integridade torna-se um ideal político quando exigimos o mesmo do Estado ou da comunidade considerados como agentes morais, quando insistimos em que o Estado aja segundo um conjunto único e coerente de princípios mesmo quando seus cidadãos estão divididos quanto à natureza exata dos princípios de justiça e equanimidade corretos?

Desse modo, a integridade deve se aplicar à equanimidade, à justiça e ao devido processo legal. E assim, poderá exigir:

(1) que os princípios políticos necessários para julgar a suposta autoridade da legislatura sejam plenamente aplicados, ao se decidir o que significa uma lei por ela sancionada; (2) que os princípios morais necessários para justificar a substância das decisões do Legislativo sejam reconhecidos pelo resto do Direito; e (3) que sejam totalmente obedecidos os procedimentos previstos nos julgamentos e que se consideram alcançar o correto equilíbrio entre exatidão e eficiência na aplicação de algum aspecto do Direito ${ }^{8}$.

É nesse sentido que a integridade, nos termos apresentados por Dworkin, pode ser desmembrada em dois princípios: a integridade na legislação e a integridade na aplicação judicial. Isto é, a exigência de que os legisladores criem normas coerentes com o direito existente, e que os aplicadores do direito sejam coerentes ao decidir o que é o direito.

Desse modo, para Dworkin, os juízes devem conceber o corpo do direito que administram como um todo, e não como uma série de decisões distintas que eles são livres para tomar ou emendar uma por uma, com nada além de um interesse estratégico pelo restante?.

Para o autor, as afirmações jurídicas são, ao mesmo tempo, posições interpretativas voltadas tanto para o passado quanto para o futuro ${ }^{10}$. O Direito é uma construção oriunda das convenções sociais e são elas que determinam quais instituições vão elaborar as leis, quais irão aplicá-las, e como devem fazer e aplicar.

Porém, não existe um direito completo, e, quando surge um problema que as leis não conseguem solucionar, o juiz utiliza da discricionariedade na aplicação do direito.

O poder discricionário não existe a não ser como um espaço vazio, circundado por uma faixa de restrições [...] por alguma razão, os padrões que uma autoridade pública deve aplicar não podem ser aplicados mecanicamente, mas exigem o uso da capacidade de julgar ${ }^{11}$.

Ao encontrar uma lacuna, uma ausência de norma para a aplicação e efetividade de um direito, o juiz precisa recorrer à discricionariedade, que, para Dworkin, só está perfeitamente à vontade em apenas um tipo de contexto: quando alguém em geral é encarregado de tomar decisões de acordo com padrões estabelecidos ${ }^{12}$. Nesse sentido, o autor ressalta que o poder discricionário de um funcionário não significa que ele é livre para decidir sem recorrer a padrões de bom senso e equidade, mas, apenas, que sua decisão não é controlada por um padrão formulado pela autoridade particular ${ }^{13}$.

7 DWORKIN, Ronald. Levando os direitos a sério. São Paulo: M. Fontes, 2002. p. 202.

8 PEDRON, Flávio Quinaud. A proposta de Ronald Dworkin para uma interpretação construtiva do direito. Revista CEJ, Brasília, Ano XIII, n. 47, p. 127-137, out./dez. 2009. p. 132.

9 DWORKIN, Ronald. Levando os direitos a sério. São Paulo: M. Fontes, 2002. p. 203.

10 DWORKIN, Ronald. Levando os direitos a sério. São Paulo: M. Fontes, 2002. p. 272-273.

11 DWORKIN, Ronald. Levando os direitos a sério. São Paulo: M. Fontes, 2002. p. 51.

12 DWORKIN, Ronald. Levando os direitos a sério. São Paulo: M. Fontes, 2002. p. 50.

13 DWORKIN, Ronald. Levando os direitos a sério. São Paulo: M. Fontes, 2002. p. 53. 
Assim, o direito não só aconselha o juiz sobre a decisão que deve tomar, mas que eles têm um dever de reconhecer e fazer vigorar certos padrões que sob a orientação de princípios que constituem o ordenamento jurídico.

Princípio é um padrão que deve ser observado, não porque vá promover ou assegurar uma situação econômica, política ou social considerada desejável, mas porque é uma exigência de justiça ou equidade ou alguma outra dimensão da moralidade ${ }^{14}$.

Desse modo, o princípio não é apreendido simplesmente como uma regra segundo a qual, tudo o que o Parlamento promulga constitui direito. Um princípio de direito deve se fundar em uma teoria do direito que possa servir de justificação para a jurisdição.

Portanto, o direito não é apenas um conjunto fixo de padrões. Assim, os elementos que os juristas devem levar em consideração, ao decidirem um problema envolvendo "direitos jurídicos", incluem proposições como os princípios.

É importante destacar que o direito se constitui de regras e princípios, e que as regras estão sujeitas a interpretações, mas os juízes não podem modificar as regras estabelecidas, pois existem padrões obrigatórios que estabelecem o limite da sua atuação, mas ressalta-se que estas estarão submetidas à interpretação, portanto, podendo ganhar sentidos diferentes.

As regras criadas por leis estão sujeitas à interpretação e reinterpretação, por vezes mesmo quando disso resulta a não execução daquilo que é chamado de "intenção do legislador". Se os tribunais tivessem o poder discricionário para modificar as regras estabelecidas, essas regras certamente não seriam obrigatórias para eles e, dessa forma, não haveria direito [...] Existem padrões, obrigatórios para os juízes, que estabelecem quando um juiz pode e quando ele não pode revogar ou mudar uma regra estabelecida ${ }^{15}$.

Surge assim o problema: quando o juiz tem permissão para mudar uma regra de direito em vigor? Para Dworkin, os princípios aparecem na resposta de duas formas: a primeira diz que é necessário que o juiz considere que a mudança da regra favorecerá algum princípio, porém não é qualquer princípio que pode justificar tal mudança, não é um critério dependente das preferências pessoais do juiz, mas deve levar em conta alguns padrões importantes que incluem, na maior parte, princípios, como o da "supremacia (?) do Poder Legislativo", um conjunto de princípios que exige que os tribunais mostrem uma deferência limitada pelos atos do Poder Legislativo.

No mesmo diapasão, Dworkin manifesta-se quanto às decisões dos tribunais:

Minha visão é que o Tribunal deve tomar decisões de princípios, não de política — decisões sobre que direitos as pessoas têm sob nosso sistema constitucional, não decisões sobre como se promover melhor o bem-estar geral - e que deve tomar essas decisões elaborando e aplicando a teoria substantiva da representação, extraída do princípio básico de que o governo deve tratar as pessoas como iguais ${ }^{16}$.

Dworkin em outras palavras afirma a necessidade de que o judiciário atue sobre os fundamentos de princípios, não é diretriz política. Duas metáforas fornecem o autor para retratar bem a ideia de integridade do direito: a do romance em cadeia e a do juiz Hércules.

Essas são ferramentas de interpretação, de reflexão, da prática jurídico-interpretativa. A ideia da metáfora do romance em cadeia pode ser sucintamente explicada da seguinte maneira: imagine que um conjunto de romancista decida escrever uma obra em conjunto. Portanto, cada um dos autores ficaria responsável por escrever um capítulo da obra, ordem que seria decidida por meio dos dados, determinando quem seria o primeiro a dar início à obra. $\mathrm{O}$ autor, por meio desse mecanismo de representação, demonstraria a necessidade de os demais autores, apesar de estes poderem mudar o trajeto da história, não poderem deixar de manter a

14 DWORKIN, Ronald. Levando os direitos a sério. São Paulo: M. Fontes, 2002. p. 36.

15 DWORKIN, Ronald. Levando os direitos a sério. São Paulo: M. Fontes, 2002. p. 59.

16 DWORKIN, Ronald. Uma questão de princípios. Trad. Luís Carlos Borges. 2. ed. São Paulo: M. Fontes, 2005. p. 101. 
coerência com os capítulos anteriormente escritos. Quer dizer, apesar de o autor do primeiro capítulo não determinar diretamente o fim da obra, o autor do último capítulo não pode deixar de manter a coerência com os fatos apresentados inicialmente, como uma corrente de ideias que se alteram, mas que mantêm o vínculo com o passado.

A ideia da Metáfora do Juiz Hercules em hipótese alguma deve ser interpretada no sentido de que se atribui ao magistrado forças as quais ele, enquanto civil, não teria. A metáfora consiste na ideia de que o magistrado deve fazer o maior esforço possível para que possa, por meio da interpretação dos Princípios, da Constituição, dos Precedentes e da história institucional, encontrar o melhor caminho para a aplicação do direito. Ou seja, o Juiz Hércules seria mais um dos intérpretes do ordenamento jurídico e da organização social, por isso deve necessariamente julgar de maneira coerente, e portanto fundamentada, todas as suas decisões, para que o próprio direito não seja desintegrado.

\section{A DistinçÃo NECESSÁRIA ENTRE A JUdICIALIZAÇÃo dA POLÍtICA E O ATIVISMO JUDICIAL}

Apesar de ambos os fenômenos serem amplamente divulgados na contemporaneidade pela literatura jurídica, muitas vezes tratados como se sinônimos fossem, ressalta-se que existem diferenças peculiares entre eles e que necessitam ser mais bem esclarecidas.

A atuação do Poder Judiciário na contemporaneidade é marcada pelas inúmeras demandas que são levadas à jurisdição constitucional. A inafastabilidade da jurisdição, não podendo o judiciário se abster de decidir uma demanda quando for provocado ${ }^{17}$; os textos constitucionais decorrentes do período pós I e II Guerra Mundial que ocasionaram o surgimento de novos direitos e de novas reivindicações por efetividade destes direitos ${ }^{18}$; o novo ordenamento jurídico com a Constituição de 1988 que rompe com o período autoritário anteriormente estabelecido ${ }^{19}$; um controle de constitucionalidade extremamente generoso e que possibilita a atuação do judiciário em assuntos diversos que necessitam de uma adequada interpretação constitucional ${ }^{20}$ são todos motivos relevantes que configuraram a autuação do judiciário.

Porém, é importante trazer à baila que, em virtude de haver a separação dos poderes, há também a independência orgânica por especializações das funções. Algumas questões que a priori deveriam ser discutidas e decididas pelo Executivo e pelo Legislativo são discutidas e decididas na jurisdição constitucional do STF.

No entanto, o Judiciário pode ter um excesso de atribuições e afirmações de direitos sob a sua responsabilidade. Isso pode ocorrer até mesmo quando os outros dois poderes aplicam suas funções constitucionais ordinárias, mas ainda pode o tribunal ser provocado a atestar a constitucionalidade do entendimento anteriormente realizado.

Os Poderes são independentes e harmônicos e devem, cada qual, a partir de suas atribuições constitucionais, interpretar e aplicar a Constituição também. Não é privilégio da jurisdição do STF a interpretação da Constituição. Os outros poderes também a interpretam e, para isso, se estabelecem os freios e contrapesos das relações institucionais.

A questão é que o Judiciário na contemporaneidade exerce uma atividade em que ele é fundamental para o cumprimento da Constituição, já que qualquer descumprimento às diretrizes constitucionais por qualquer um dos Poderes também caberá provocação, para que, a partir do devido processo constitucional, "efetive" os direitos dos cidadãos. ${ }^{21}$

17 BARROSO, Luiz Roberto. Judicialização, ativismo judicial e legitimidade democrática. Revista de direito do Estado de Salvador, n. 13, jan./mar. 2009.

18 TASSINARI, Clarissa. Jurisdição e ativismo judicial: limites da atuação do judiciário. Porto Alegre: Livraria do Advogado, 2013.

19 TASSINARI, Clarissa. Jurisdição e ativismo judicial: limites da atuação do judiciário. Porto Alegre: Livraria do Advogado, 2013. p. 25.

20 BARROSO, Luiz Roberto. Judicialização, ativismo judicial e legitimidade democrática. Revista de direito do Estado de Salvador, n.

13, jan./mar. 2009.

21 O destaque em "efetive" é para demonstrar cuidado para que não haja uma banalização do termo. 
Isso é o que o autor Bercovici chama de "instrumentalismo constitucional", quer dizer, "consagrados os direitos pelo texto constitucional, basta apenas que o judiciário os aplique". ${ }^{22}$

\subsection{A judicialização da política}

É nesse cenário jurídico, de excesso de litigiosidade, que o fenômeno da judicialização da política emerge no ordenamento jurídico brasileiro. O que se constata é que a vocação expansionista do princípio democrático tem implicado uma crescente institucionalização do direito na vida social, invadindo espaços até a pouco inacessíveis a ele, como certas dimensões da vida privada. ${ }^{23}$

Não há razão para a consumação desse fenômeno. Tanto a estrutura institucional erguida pelo poder constituinte como os fatores históricos, políticos e sociológicos são importantes para pensar o fenômeno da judicialização da política.

Nessa perspectiva, Pogrebinschi afirma que:

Um fato que não pode mais deixar de ser ouvido sob o risco de ficar-se surdo, posto que fala cada vez mais alto, é o crescimento do papel institucional das cortes constitucionais e seu impacto político nas democracias contemporâneas. Esse não é um fato novo, porém é um fato que vem ganhando cada vez mais força e tornando-se paulatinamente mais explícito em lugares onde não o era antes. No Brasil, em particular, é um fato relativamente recente, que vem assumindo proeminência veloz e, ao que tudo indica, inexorável ${ }^{24}$.

Quando o judiciário é chamado a garantir um tratamento terapêutico, por exemplo, não faz nada além da sua própria atividade ordinária de concretizar os direitos fundamentais do cidadão litigante. Para Streck e Morais:

A democracia é a única sociedade e o único regime político que considera o conflito legítimo, uma vez que não só trabalha politicamente os conflitos de necessidades e de interesses, como procura instituí-los como direitos e, como tais, exige que sejam reconhecidos e respeitados. ${ }^{25}$

O Judiciário não pode deixar de julgar casos de direitos em que é chamado a decidir, portanto, judicialização da política faz parte do rearranjo institucional que a democracia exige para que os direitos sejam respeitados. Mas, apesar de ser necessário o julgamento do Judiciário, esse não pode substituir "a arena pública de deliberação e formação da vontade pública institucionalizada"26. Veja o que dispõem Oliveira, Bahia e Nunes a respeito:

"Casos urgentes podem (e devem) receber "proteção" do Judiciário, mas haverá uma confusão entre "questões de princípio" e "questões de política" se a arena representativa for relegada a segundo plano e o Judiciário transformado em promotor de políticas públicas"27.

Grande parte dessas novas demandas que chegam ao tribunal constitucional diz respeito a temas que envolvem questões de políticas públicas e passa a fazer parte da jurisdição constitucional. É o contencioso do judiciário. Mas é importante esclarecer que, também, é do exercício do Poder Judiciário fazer a separa-

22 TASSINARI, Clarissa. Jurisdição e ativismo judicial: limites da atuação do judiciário. Porto Alegre: Livraria do Advogado, 2013. p. 37.

23 VIANNA, Luiz Werneck et al. A judicialização da política e das relações sociais no Brasil. Rio de Janeiro: Renavan, 1999. p. 15.

24 POGREBINSCHI, Thamy. Judicialização ou representação?: política, direito e democracia no Brasil. Rio de Janeiro: Elsevier, 2011. p. 175.

25 STRECK, Lenio Luis; MORAIS, José Luis Bolzan de. Ciência politica e teoria do Estado. 6. ed. Porto Alegre: Livraria do Advogado, 2008. p. 109.

26 OLIVEIRA, Marcelo Andrade Cattoni de; BAHIA, Alexandre Melo Franco; NUNES, Dierle. Controle de constitucionalidade é jurídico, não político. 30 de abril de 2013. Disponível em: < http://www.conjur.com.br/2013-abr-30/sistema-controle-constitucionalidade-judicial-nao-politico>. Acesso em: 06 out. 2013. p. 62.

27 OLIVEIRA, Marcelo Andrade Cattoni de; BAHIA, Alexandre Melo Franco; NUNES, Dierle. Controle de constitucionalidade é jurídico, não político. 30 de abril de 2013. Disponível em: < http://www.conjur.com.br/2013-abr-30/sistema-controle-constitucionalidade-judicial-nao-politico >. Acesso em: 06 out. 2013. 
ção dos argumentos de política (diretrizes políticas) e de direito (princípios), uma vez que se trata de uma democracia constitucional. ${ }^{28}$

O problema é que o judiciário sempre se encontra diante de um dilema: se assume postura intervencionista, imiscuindo-se até mesmo no controle de políticas públicas, é acusado de ativista [...]; se assume uma postura self-restrainting [...] é criticado pela sua timidez ou conservadorismo. ${ }^{29}$

Importante ressaltar aqui que Streck assume postura quanto ao tema:

Afinal, de um lado, critica-se a invasão da esfera da legislação a partir do que os procedimentalistas chamam de ativismo judicial, jurisprudência de valores, comunitarismo ou constitucionalismo de efetividade; de outro, tem sido lamentado o uso da tese da reserva do possível e de outros artifícios de caráter self restraintig, aplicados indevidamente pelo Supremo Tribunal Federal. De minha parte, sempre tenho defendido a possibilidade da utilização da jurisdição constitucional para realizar direitos fundamentais sociais (inclusive, de políticas públicas), criticando, com veemência, a objeção representada pela invocação da "reserva do possível"

A judicialização da política deriva de uma série de fatores que muitas vezes são alheios à jurisdição, mas que estão diretamente vinculados ao maior reconhecimento de direitos pelos cidadãos e pela ineficiência do Estado em implementá-los, o que ocasiona, portanto, "aumento de litigiosidade — característica da socie-

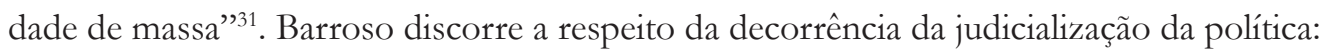

A judicialização, no contexto brasileiro, é um fato, uma circunstância que decorre do modelo constitucional que se adotou, e não um exercício deliberado de vontade política. Em todos os casos referidos acima, o Judiciário decidiu porque era o que lhe cabia fazer, sem alternativa. Se uma norma constitucional permite que dela se deduza uma pretensão, subjetiva ou objetiva, ao juiz cabe dela conhecer, decidindo a matéria ${ }^{32}$.

$\mathrm{Na}$ verdade, a judicialização da política reflete o Judiciário que possui como pressuposto primeiro a defesa da Constituição e dos direitos fundamentais. Por isso a judicialização da política não extrapola a função típica do Judiciário. Cabe lembrar a visão do exercício da judicialização da política e das relações sociais a partir do olhar sociológico:

De fato, a judicialização da política e das relações sociais, se significar a delegação da vontade do soberano a um corpo especializado de peritos na interpretação do direito e a "substituição" de um Estado benefactor por uma justiça providencial e de moldes assistencialistas, não será propícia à formação de homens livres e nem à construção de uma democracia de cidadãos ativos. Contudo, a mobilização de uma sociedade para a defesa dos seus interesses e direitos, em um contexto institucional em que as maiorias efetivas da população são reduzidas, por uma estranha alquimia eleitoral, em minorias parlamentares, não pode desconhecer os recursos que the são disponíveis a fim de conquistar uma democracia de cidadãos. Do mesmo modo, uma vida associativa ainda incipiente, por décadas reprimida no seu nascedouro, não se pode recusar a perceber as novas possibilidades, para a reconstituição do tecido da sociabilidade, dos lugares institucionais que lhe são facultados pelas novas vias de acesso à justiça. ${ }^{33}$

28 "No fundo o que se apresenta aqui é o constitucionalismo como um movimento político-ideológico que procura criar mecanismos para limitação do exercício do poder político. Limitação essa que se caracteriza e se define na ideia de império da lei, em contraposição a uma vontade política soberana daquele que exerce o poder político" TASSINARI, Clarissa. Jurisdição e ativismo judicial: limites da atuação do judiciário. Porto Alegre: Livraria do Advogado, 2013. p. 28. Sabe-se também muito bem, com as contribuições de Carl Schmitt, que prejudicaria e muito a transformação do Poder Judiciário em um órgão político: "Como frequentemente eu tenho a ocasião de advertir, tanto para o Direito constitucional como para o Direito das gentes, a consequência não seria uma judicialização da política, mas uma politização da justiça." (tradução livre). (SCHMITT, 1983, p. 57). No original: Como frecuentemente he tenido ocasión de advertir tanto para el Derecho constitucional como para el Derecho de gentes, la consecuencia no sería una judicialización de la Política, sino una politiquización de la Justicia".

29 STRECK, Lenio Luiz. A atualidade do debate da crise paradigmática do direito e a resistência positivista ao neoconstitucionalismo. Revista do Instituto de Hermenêutica Jurídica, Porto Alegre, n. 4, p. 223-262, 2006.

30 STRECK, Lenio Luiz. A atualidade do debate da crise paradigmática do direito e a resistência positivista ao neoconstitucionalismo. Revista do Instituto de Hermenêtica Jurídica, Porto Alegre, n. 4, p. 223-262, 2006.

31 TASSINARI, Clarissa. Jurisdição e ativismo judicial: limites da atuação do judiciário. Porto Alegre: Livraria do Advogado, 2013. p. 32 .

32 BARROSO, Luiz Roberto. Judicialização, ativismo judicial e legitimidade democrática. Revista de direito do Estado de Salvador, n. 13, p. 6, jan./mar. 2009.

33 VIANNA, Luiz Werneck et al. A judicialização da política e das relações sociais no Brasil. Rio de janeiro: Renavan, 1999. p. 43. 
Ainda na mesma linha de raciocínio, Cittadino revela que:

[...] o processo de judicialização da política não precisa invocar uma ação paternalista por parte do Poder Judiciário. A própria Constituição de 1988 instituiu diversos mecanismos processuais que buscam dar eficácia aos seus princípios, e essa tarefa é de responsabilidade de uma cidadania juridicamente participativa que depende, é verdade, atuação dos tribunais, mas, sobretudo, do nível de pressão e mobilização política que, sobre eles, se fizer ${ }^{34}$.

Não é um ato que seja realizado por livre vontade ou por interferência proposital do judiciário. Como dito acima: é um ato que advém do contencioso. Bahia e Nunes advertem: "a judicialização serviria como técnica compensatória das deficiências das outras funções estatais (Executivo e Legislativo) em face de sua propagada ineficiência o que obscurece a crise institucional dessas funções" ${ }^{35}$. Barroso ao citar as causas da judicialização da política, as divide em três:

A primeira é a "redemocratização do país que teve como ponto culminante a promulgação da Constituição de 1988". A segunda é a abrangência da Constituição, quer dizer, em outras palavras, o fato de ela ser analítica e algumas vezes prolixa. A terceira causa é a abertura proporcionada pelo sistema de controle de constitucionalidade, que, ao ver do Ministro, é muito generosa ${ }^{36}$.

Ainda nessa mesma esteira, o Ministro Gilmar Ferreira Mendes, em seu livro Jurisdição Constitucional, afirma que grande parte do motivo da judicialização está também no fato de a Constituição adotar modelo generoso de controle de constitucionalidade por ter como referência o modelo Europeu e o Norte-americano, quer dizer, modelo concentrado e difuso de constitucionalidade, atribuindo grande atuação ao judiciário no que diz respeito à validade normativa. ${ }^{37}$

A organização institucional deve ser pautada pelo exercício regular das atribuições de cada Poder, em consonância com suas funções ordinárias, de forma a não se pautar pela judicialização da política. Porém, a grande questão é que tanto o Poder Legislativo quanto o Poder Executivo têm, atualmente, deixado de realizar alguns de seus atos típicos concedidos por meio da representação política decorrente do voto popular. ${ }^{38}$

Grande parte dos países, após a Segunda Guerra Mundial, teve a ocupação da cultura constitucionalista sobreposta à política majoritária. Essa perspectiva comparada é muito interessante para se perceber que não se trata de uma questão estritamente brasileira:

No Canadá, a Suprema Corte foi chamada a se manifestar sobre a constitucionalidade de os Estados Unidos fazerem testes com mísseis em solo canadense. Nos Estados Unidos, o último capítulo da eleição presidencial de 2000 foi escrito pela Suprema Corte, no julgamento de Bush v. Gore. Em Israel, a Suprema Corte decidiu sobre a compatibilidade, com a Constituição e com atos internacionais, da construção de um muro na fronteira com o território palestino. A Corte Constitucional da Turquia tem desempenhado um papel vital na preservação de um Estado laico, protegendo-o do avanço do fundamentalismo islâmico. Na Hungria e na Argentina, planos econômicos de largo alcance tiveram sua validade decidida pelas mais altas Cortes. Na Coreia, a Corte Constitucional restituiu o mandato de um presidente que havia sido destituído por impeachment. . $^{39}$.

34 CITTADINO, Gisele. Judicialização da política, constitucionalismo democrático e separação de poderes. In: VIANNA, Luiz Werneck (Org.) A democracia e os três poderes no Brasil. Belo Horizonte: Editora UFMG, 2003. p. 39.

35 OLIVEIRA, Marcelo Andrade Cattoni de; BAHIA, Alexandre Melo Franco; NUNES, Dierle. Controle de constitucionalidade é jurídico, não político. 30 de abril de 2013. Disponível em: < http://www.conjur.com.br/2013-abr-30/sistema-controle-constitucionalidade-judicial-nao-politico>. Acesso em: 06 out. 2013.

36 BARROSO, Luiz Roberto. Judicialização, ativismo judicial e legitimidade democrática. Revista de direito do Estado de Salvador, n. 13, p. 3, jan./mar. 2009.

37 MENDES, Gilmar Ferreira. Jurisdição constitucional: o controle abstrato de normas no Brasil e na Alemanha. 5. ed. São Paulo: Saraiva, 2005.

38 Para os autores Bahia e Nunes: [...] a crise da democracia representativa tem levado, cada vez mais, demandas ao judiciário. Após a Constituição de 1988, ele tem sido utilizado como tertium genus diante da inacessibilidade de grupos ou demandas minoritários aos outros poderes. (BAHIA E NUNES, 2010, p. 62)

39 BARROSO, Luiz Roberto. Judicialização, ativismo judicial e legitimidade democrática. Revista de direito do Estado de Salvador, n. 13, p. 124-5, jan./mar. 2009. 
Faz-se necessária menção dos limites de atuação do Poder Judiciário e de uma realidade que se pode constatar por meio das atuações dele em diversos países do mundo, bem como bem fizeram pioneiramente Neal Tate e Torbjon Vallinder no campo das ciências sociais. ${ }^{40}$ A obra organizada pelos autores em 1995 conta com a presença de outros colaboradores que pertencem a diversas tradições jurídicas e mostrou que a expansão do direito, mais precisamente a problematização das intervenções judiciais, ocorreu em vários países sob a influência americana de jurisdição. Tassinari discorre a respeito:

Isto é, este movimento de intensificação da atividade judiciária, que contemporaneamente se vislumbra numa perspectiva global, já foi vivenciado pelos Estados Unidos, que, em razão disso, desde a instituição do controle de constitucionalidade (judicial review) em 1803, produziu um número de acervo literário, problematizando as atribuições, limites e competências do Poder Judiciário ${ }^{41}$.

Em suma, a judicialização da política não depende da vontade do órgão judicante, mas é uma demanda social que é ocasionada por reivindicações de direitos, acarretando aumento de litigiosidade.

Certo é que os poderes da União estarão em constante ajuste institucional na medida em que as demandas políticas emergirem na realidade institucional. A própria Constituição trata de realizar esses limites institucionais dos Poderes da União. Assim, não há que se falar em intervenção funcional de um Poder sob o outro. São especializações que a própria Constituição estabelece para as devidas funções dos seus Poderes, assim, a judicialização não pode ser interpretada como fenômeno prejudicial à democracia constitucional.

Nesse sentido, Pogrebinschi conclui:

O crescimento do papel político das cortes constitucionais consiste em uma oportunidade para a democracia exercer sua vocação experimentalista. Isso implica concebê-lo não como uma usurpação de funções das instituições representativas, mas como uma ampliação daquilo que se considera função representativa ${ }^{42}$.

A tomada de decisão do STF a respeito de temas políticos em que ele é chamado a decidir pode elevar o seu apreço social. A aceitação popular deve ser cautelosamente pensada no ordenamento jurídico brasileiro para evitar que condutas paternalistas e protagonistas ocorram sob esse clamor.

Por esse motivo deve-se distinguir a judicialização da política, fenômeno ordinário do contencioso do STF, do ativismo judicial, que, por outro lado, se apresenta como um excesso do Judiciário no exercício de suas atribuições constitucionais.

\subsection{O Ativismo Judicial}

O estudo sobre o ativismo judicial será necessário para apontar que, apesar dos diversos avanços políticos e jurídicos ocorridos no país, que são frutos de conquistas democráticas, ainda pode observar sua presença nas instituições brasileiras que praticam políticas ilegítimas pautadas na relação de custo benefício (utilitárias).

A democracia constitucional é incompatível com a atitude discricionária e decisionista, já que não cabe ao Judiciário fazer interpretação subjetivista para a tomada de decisão. Cabe sim aplicar os princípios de justiça e viabilizar os direitos fundamentais a partir da aplicação da Constituição.

Introdutoriamente, o ativismo judicial surge no seguinte contexto:

A locução "ativismo judicial” foi utilizada, pela primeira vez, em artigo de um historiador sobre a Suprema Corte americana no período do New Deal, publicado em revista de circulação ampla. V. SCHLESINGER,

40 Para saber mais: TATE, N.; VALLINDER, T. The Global Expansion of judicial power: the judicialization of politics. In: The global expansion of judicial power. New York: New York University Press, 1995.

41 TASSINARI, Clarissa. Jurisdição e ativismo judicial: limites da atuação do judiciário. Porto Alegre: Livraria do Advogado, 2013. p. 39 .

42 POGREBINSCHI, Thamy. Judicialização ou representação?: política, direito e democracia no Brasil. Rio de Janeiro: Elsevier, 2011. p. 175. 
Arthur M., Jr., The Supreme Court: 1947. Fortune, jan. 1947, v. 35, p. 208 apud KMIEC, Keenan D. The origin and current meanings of 'judicial activism'. California Law Review, out.2004, n. 92, p. 1446”. ${ }^{43}$

O conceito de ativismo judicial deve ser pensado a partir da ingerência do Judiciário às especialidades e separação dos outros Poderes, tornando-o a principal instituição proporcionadora da democracia, acima e mais importante que as demais.

Veja afirmativa de Vieira ao problematizar tema de seu artigo denominado Supremocracia:

O STF está hoje no centro de nosso sistema político, fato que demonstra a fragilidade de nosso sistema representativo. Tal tribunal vem exercendo, ainda que subsidiariamente, o papel de criador de regras, acumulando a autoridade de intérprete da constituição com o exercício de poder legislativo, tradicionalmente exercido por poderes representativos ${ }^{44}$.

Nos Estados Unidos, por exemplo, esse tema não é enfrentado somente em 1947, já que desde o início do controle de constitucionalidade, em 1803, já se debate os limites de atuação dos Poderes.

O ativismo judicial é a interpretação que vai além da possibilidade principiológica constitucionalmente prevista. Apesar do papel da atividade do Judiciário estar em movimento crescente desde a segunda guerra mundial, ele deve ser restrito à justificação pública e à razão pública para a aplicação coerente dos princípios de justiça.

Para Ramos, o ativismo judicial pode ser conceituado como

O exercício da função jurisdicional para além dos limites impostos pelo próprio ordenamento que incumbe, institucionalmente, ao Poder Judiciário fazer atuar, resolvendo litígios de feições subjetivas (conflitos de interesse) e controvérsias jurídicas de natureza objetiva (conflitos normativos) ${ }^{45}$.

O que caracteriza o ativismo é o fato de o Judiciário passar a atuar fora das suas atribuições constitucionais, ao fazer a vez do Legislativo, principalmente, gerando uma crise de legitimidade na democracia brasileira. Veja Streck a respeito:

Este é o ponto. Com essa postura ativista do judiciário, não apenas argumentos de política passaram a predar os argumentos jurídicos, mas também o judiciário passou a exercer este papel predatório do espaço político (e da moral), na medida em que, ao desrespeitar os limites materiais estabelecidos pela Constituição para sua atuação, acabou trazendo imenso prejuízo para a democracia ${ }^{46}$.

A inafastabilidade da jurisdição, a dificuldade do legislativo corresponder às modificações e demandas sociais, dentre outros motivos, também são relevantes e contribuem para que acarrete em ativismo do judiciário, ora o Judiciário pode usar de argumentos meta-jurídicos, ora pode ser legislador judicial. ${ }^{47}$

No ativismo judicial, constrói-se a justificação pública a partir de doutrinas abrangentes específicas que, na concepção do justo, utilizam fundamentos de algum conceito particular de vida boa. É exatamente a ação repudiada por Dworkin; o Judiciário não pode utilizar de argumentos políticos na construção da decisão, devendo este se pautar nos princípios do direito.

Será sempre o ativismo uma atitude perniciosa do Judiciário. Atribui-se sentido pejorativo ao ativismo judicial, uma vez que não respeita a harmonia e independência dos poderes, seja na interpretação da Constituição, seja no diálogo institucional de deferência de ações recíprocas e/ou, principalmente, no compromisso de aplicação dos princípios do direito.

43 BARROSO, Luiz Roberto. Constituição, democracia e supremacia judicial: direito e política no Brasil contemporâneo. RfdRevista da Faculdade de Direito- Uerj, v. 2, n. 21, p. 8, jan./jun. 2012.

44 VIEIRA, Oscar Vilhena. Supremocracia. Rev. direito GV [online]. v. 4, n. 2, p. 441-463, 2008.

45 RAMOS, Elival da Silva. Ativismo judicial: parâmetros dogmáticos. São Paulo: Saraiva, 2010. p. 219.

46 STRECK, Lenio Luiz. Prefácio. In: TASSINARI, Clarissa. Jurisdição e ativismo judicial: limites da atuação do judiciário. Porto Alegre: Livraria do Advogado, 2013. p. 12.

47 STRECK, Lenio Luiz. Emenda dos Precatórios: STF pode legislar? Não! Disponível em: <http://www.conjur.com.br/2013-out-31/ senso-incomum-emenda-precatorios-stf-legislar-nao2>. Acesso em: 06 nov. 2013. 
O ativismo jurídico, ao contrário da judicialização da política, constitui ato de "vontade" do judiciário, ou melhor, confusão entre fundamentos de princípios de justiça (direito) e diretrizes políticas (política), mas que ocorre por clara opção jurisdicional.

O ativismo está envolvido com a construção da decisão que utiliza em seus fundamentos argumentos políticos. Dworkin, por exemplo, vincula o ativismo ao pragmatismo jurídico, uma maneira consequencialista de ver as ações judiciais:

O ativismo é uma forma virulenta de pragmatismo jurídico. Um juiz ativista ignoraria o texto da Constituição, a história de sua promulgação, as decisões anteriores da Suprema Corte que buscaram interpretá-la e as duradouras tradições de nossa cultura política. $\mathrm{O}$ ativista ignoraria tudo isso para impor a outros poderes do Estado seu próprio ponto de vista sobre o que a justiça exige ${ }^{48}$.

Não se pode fazer vinculação do ativismo judicial com a atividade intensa do judiciário, realizando análise exclusivamente quantitativa. Essa análise quantitativa pode ser um indício de ativismo, mas não é suficiente para diagnosticá-lo. Ou seja, o fato de o STF assumir, em grande parte, a concretização de direitos fundamentais que dizem respeito às políticas públicas, por exemplo, não é fundamento por si só para se concluir que haja ativismo. $\mathrm{O}$ ativismo judicial está diretamente ligado ao não respeito à relação necessária que deve haver entre o Judiciário, devido processo constitucional e a fundamentação das decisões.

Por isso, para enfrentar diretamente o problema do ativismo judicial, deve-se tratar da teoria da decisão judicial de Dworkin. Ela subsidia a afirmativa de que a questão do ativismo está no momento de construção das decisões, podendo, assim, afirmar que, em algum julgado, o STF julgou politicamente.

Veja por exemplo, confusão do Ministro do STF Celso de Mello acerca do conceito de ativismo judicial ao julgar o caso que versou a respeito da constitucionalidade da união homoafetiva como entidade familiar:

Práticas de ativismo judicial, embora moderadamente desempenhadas pela Corte Suprema em momentos excepcionais, tornam-se uma necessidade institucional, quando os órgãos do Poder Público se omitem ou retardam, excessivamente, o cumprimento de obrigações a que estão sujeitos ${ }^{49}$.

Diante do conceito trabalhado neste estudo, não é um caso de ativismo judicial garantir iguais direitos às pessoas, ainda é a ocorrência do fenômeno denominado de judicialização da política.

Na mesma esteira, o ministro Barroso revela entendimento diferente do que esta pesquisa sustenta. Para ele, o ativismo judicial:

“(...) expressa uma postura do intérprete, um modo proativo e expansivo de interpretar a Constituição, potencializando o sentido e alcance de suas normas, para ir além do legislador ordinário”. ${ }^{50}$

O autor ao caracterizar a postura ativista com o modo proativo ou ainda, a partir de interpretação extensiva do tribunal, mostra que ainda está preso à ideia de legislador ordinário, não trabalhando, portanto, sob pressupostos principiológicos da interpretação.

Para que se evite o ativismo judicial é necessária a compreensão adequada de quais são os limites de atuação do Judiciário, bem como de quais são os requisitos necessários para que sua atividade jurisdicional seja legítima. A linha é tênue entre a judicialização da política e o ativismo judicial. O problema do ativismo judicial é um problema de qualidade da decisão, não da quantidade de decisão que o tribunal profere. ${ }^{51}$

Para o momento, o escopo é investigar se o devido processo constitucional está sendo respeitado no ato de realização das audiências públicas. Os atos jurisdicionais que não respeitam o devido processo constitu-

48 DWORKIN, Ronald. O império do direito. Trad. Jefferson Luiz Camargo. 2. ed. São Paulo: M. Fontes, 2007. p. 452.

49 BRASIL. Supremo Tribunal Federal. ADI 4277, j. 05.05.2011, voto do Min. Celso de Mello, p. 46. Disponível em: <http:// www.stf.jus.br/portal/geral/verPdfPaginado.asp?id=400547\&tipo=TP\&descricao=ADI\%2F4277>. Acesso em: 25 set. 2014.

50 BARROSO, Luiz Roberto. Judicialização, ativismo judicial e legitimidade democrática. Revista de direito do Estado de Salvador, n. 13, p. 17, jan./mar. 2009.

51 Importante ressaltar aqui que Veríssimo (2008) e Progrebinschi (2011) fazem relação da judicialização da política com o número de deferências do STF aos entendimentos do Congresso Nacional no controle de constitucionalidade. 
cional não possuem a preocupação de garantir uma jurisdição constitucional democrática.

O problema do ativismo judicial deve estar vinculado ao fato de existir a atividade discricionária do Judiciário e a compreensão de que ele possui o monopólio de dizer o direito; a ausência de critérios claros que determinam o procedimento específico de construção da decisão, a impossibilidade de interposição de recursos; de obscuridade quanto aos termos repercussão geral e interesse público relevante, mutação constitucional, lesão grave e de difícil reparação, dentre outros. Se essas características estiverem no bojo da atividade jurisdicional do STF, a vinculação entre o ativismo judicial e o utilitarismo ficará demonstrada no ato de fundamentação da decisão.

\subsection{A distinção aplicada na prática de atuação da jurisdição constitucional}

Nesse momento, a pesquisa passa pela análise de alguns dos principais julgados do STF nos últimos anos para que, por meio do estudo da fundamentação destes, possa-se identificar os argumentos sustentados quanto à diferenciação da judicialização da política e do ativismo judicial.

Inicia-se com exemplos referentes a decisões que envolvem a judicialização da política, para depois apresentar decisões referentes ao ativismo judicial, e assim, se tornar possível apontar os elementos diferenciadores dos dois fenômenos.

\section{a) Direito a greve}

O primeiro exemplo diz respeito ao direito de greve, um direito constitucionalmente previsto, no artigo $9^{\circ}$ da Constituição da República de 1988, que diz: "É assegurado o direito de greve, competindo aos trabalhadores decidir sobre a oportunidade de exercê-lo e sobre os interesses que devam por meio dele defender". 52

Por um lado, não existe uma lei que dispõe sobre a greve para os funcionários públicos, por outro, o Poder Legislativo se mantém inerte e não legisla para garantir o direito dos servidores. Quando o Poder Judiciário é provocado para efetivar o direito de greve e decide declarar que todos possuem esse direito e, por maioria dos votos, determina aplicar ao setor público, no que couber, a lei de greve vigente no setor privado (Lei no 7.783/89) é um caso de judicialização da política, uma vez que deveria o legislativo garantir esse direito, mas em sua ausência, declara e assegura o direito o Poder Judiciário. Veja:

EMENTA: Mandado de Injunção. Garantia fundamental (CF, art. 5º inciso LXXI). Direito de greve dos servidores públicos civis (CF, art. 37, inciso VII). Evolução do tema na jurisprudência do Supremo Tribunal Federal (STF). Definição dos parâmetros de competência constitucional para apreciação no âmbito da justiça federal e da justiça estadual até a edição da legislação específica pertinente, nos termos do art. 37, VII, da CF. Em observância aos ditames da segurança jurídica e à evolução jurisprudencial na interpretação da omissão legislativa sobre o direito de greve dos servidores públicos civis, fixação do prazo de 60 (sessenta) dias para que o Congresso Nacional legisle sobre a matéria. Mandado de injunção deferido para determinar a aplicação das leis nos 7.701/1988 e 7.783/1989.

A decisão foi tomada no julgamento dos Mandados de Injunção 670, 708 e 712, ajuizados, respectivamente, pelo Sindicato dos Servidores Policiais Civis do Estado do Espírito Santo, pelo Sindicato dos Trabalhadores em Educação do Município de João Pessoa e pelo Sindicato dos Trabalhadores do Poder Judiciário do Estado do Pará.

Os sindicatos buscavam assegurar o direito de greve para seus filiados e reclamavam da omissão legislativa do Congresso Nacional em regulamentar a matéria, conforme determina o artigo 37, inciso VII, da Constituição Federal.

Ao resumir o tema, o ministro Celso de Mello salientou que:

52 BRASIL. Constituição (1988). Constituição da República Federativa do Brasil. Brasília: Senado, 1988. 
Não mais se pode tolerar, sob pena de fraudar-se a vontade da Constituição, esse estado de continuada, inaceitável, irrazoável e abusiva inércia do Congresso Nacional, cuja omissão, além de lesiva ao direito dos servidores públicos civis - a quem se vem negando, arbitrariamente, o exercício do direito de greve, já assegurado pelo texto constitucional —, traduz um incompreensível sentimento de desapreço pela autoridade, pelo valor e pelo alto significado de que se reveste a Constituição da República ${ }^{53}$.

O que temos nessa decisão é a inércia do Poder Legislativo em exercer sua função legisladora para garantir o direito constitucional de greve. Assim, frente à demanda de efetividade do direito, o STF necessitou fazer valer a Constituição, o que é o seu dever, não extrapolando sua competência.

\section{b) Antecipação do parto do feto anencefálico}

A possibilidade de antecipação do parto em caso de feto anencefálico foi objeto de julgamento da ADPF 54, ação que foi distribuída em 17/06/2004, e interposta pela Confederação Nacional dos Trabalhadores da Saúde do Brasil, tendo como relator o Ministro Marco Aurélio. Basicamente, a discussão era sobre o pleno direito da mulher de escolher, no caso de anencefalia, pelo parto de forma antecipada. Porém, surgiram inúmeras questões polêmicas, como a criminalização do aborto, o direito à vida, a dignidade humana. Para muitos, esse foi um dos mais importantes julgamentos que o Supremo Tribunal Federal já realizou, em toda a histórica republicana.

Diante da notícia de estarem gerando fetos anencefálicos, e de que não existe possibilidade de vida extrauterina, as mulheres procuravam o Poder Judiciário pugnando pela antecipação terapêutica do parto, como uma forma de reduzir o sofrimento de carregar um ser, durante nove meses, sabendo que o mesmo morreria logo após a sua retirada do útero materno.

Ocorre que, o aborto é criminalizado no Brasil, e não havia entendimento pacificado para a permissão da antecipação do parto em caso de anencefalia. Embasando, no direito à dignidade humana, que é um dos pilares basilares da Constituição, as mulheres pleitearam ao STF a possibilidade de antecipar o parto em tal caso. E, assim, decidiu a Corte:

\section{c) Reconhecimento da união homoafetiva}

Outro tema de suma relevância no que tange à jurisdição constitucional foi o reconhecimento da união homoafetiva, no julgamento da Ação Direta de Inconstitucionalidade (ADI) 4277 e a Arguição de Descumprimento de Preceito Fundamental (ADPF) 132, reconhecendo a união estável para casais do mesmo sexo.

As ações foram proposta no STF pela Procuradoria-Geral da República e pelo governador do Rio de Janeiro, Sérgio Cabral. O argumento da decisão gira em torno de que o artigo $3^{\circ}$, inciso IV, da CF veda qualquer discriminação em virtude de sexo, raça, cor e que, nesse sentido, ninguém pode ser diminuído ou discriminado em função de sua preferência sexual. Nesse sentido, é preciso dar interpretação, conforme a Constituição Federal, para excluir qualquer significado do artigo 1.723 do Código Civil que impeça o reconhecimento da união entre pessoas do mesmo sexo como entidade familiar.

EMENTA: 1. [...] União homoafetiva e seu reconhecimento como instituto jurídico. [...] Encampação dos fundamentos da ADPF n ${ }^{\circ} 132-\mathrm{RJ}$ pela $\mathrm{ADI} \mathrm{n}^{\circ}$ 4.277-DF, com a finalidade de conferir "interpretação conforme à constituição" ao art. 1.723 do Código Civil. Atendimento das condições da ação. 2. Proibição de discriminação das pessoas em razão do sexo, seja no plano da dicotomia homem/mulher (gênero), seja no plano da orientação sexual de cada qual deles. A proibição do preconceito como capítulo do constitucionalismo fraternal. Homenagem ao pluralismo como valor sócio-político-cultural. Liberdade para dispor da própria sexualidade, inserida na categoria dos direitos fundamentais do indivíduo, expressão que é da autonomia de vontade. Direito à intimidade e à vida privada. Cláusula pétrea [...] 3. Tratamento constitucional da instituição da família. Reconhecimento de que a constituição federal não empresta ao substantivo "família" nenhum significado ortodoxo ou da própria técnica jurídica. A família como categoria sociocultural e princípio espiritual. Direito subjetivo de constituir família. Interpretação

53 SUPREMO determina aplicação da lei de greve dos trabalhadores privados aos servidores públicos. Disponível em: < http:// www.stf.jus.br/portal/cms/verNoticiaDetalhe.asp?idConteudo $=75355>$. 
não-reducionista. [...] 4. União estável. Normação constitucional referida a homem e mulher, mas apenas para especial proteção desta última. Focado propósito constitucional de estabelecer relações jurídicas horizontais ou sem hierarquia entre as duas tipologias do gênero humano. Identidade constitucional dos conceitos de "entidade familiar" e "família". 6. Interpretação do art. 1.723 do código civil em conformidade com a constituição federal (técnica da "interpretação conforme”). Reconhecimento da união homoafetiva como família. Procedência das ações.

O STF, nesse caso, precisa agir para excluir do dispositivo do Código Civil, qualquer interpretação que impeça o reconhecimento da união contínua, pública e duradoura entre pessoas do mesmo sexo como família. Mais uma vez, trata-se de efetivação de direitos advindos de reivindicações sociais, das quais o Poder Judiciário não pode, nem deve ficar inerte.

Adentrando em um segundo momento, a pesquisa agora trabalha com casos em que, de acordo com o exposto ao longo deste trabalho, o STF agiu extrapolando sua função constitucional, violando a Separação dos Poderes, proferindo decisões com argumentos políticos, para que atingisse determinado interesse de classe específica. Não se trata de efetividade de direitos, mas sim de distorção de função.

\section{a) A interpretação do art. 52, inciso $X$, da Constituição}

Agora temos a decisão da Reclamação 4.335/AC, pela qual o STF decidiu, ao menos provisoriamente que o artigo 52, inciso X, da Constituição é anacrônico. Tal dispositivo constitucional diz que cabe ao Senado Federal suspender a execução de lei declarada inconstitucional. O Supremo Tribunal Federal nega validade a um dispositivo da Constituição originária, que trata da relação direta entre os poderes de Estado, e isso é ativismo judicial.

A Reclamação no 4.335/AC, de relatoria do Ministro Gilmar Ferreira Mendes, foi proposta pela Defensoria Pública da União, para questionar a decisão de um juiz do Estado do Acre que afastou o entendimento do STF no que tange à inconstitucionalidade da vedação de progressão de regime de cumprimento de pena pela Lei de Crimes Hediondos (Lei Federal no 8.072, de 1990), posição esta firmada em sede de controle de constitucionalidade difuso, tendo portanto, que respeitar a regra de seus efeitos inter partes.

O Plenário do Supremo Tribunal declarou incidenter tantum a inconstitucionalidade do art. $2^{\circ}, \int 1^{\circ}$ da Lei 8.072/90, por via do Habeas Corpus n. 82.959. Como a decisão se deu no controle difuso de constitucionalidade, a decisão do STF, em respeito ao disposto no art. 52, inciso X, da CR/88, teria que ser comunicada ao Senado para que o parlamento providenciasse a suspensão da eficácia do dispositivo declarado inconstitucional, que discricionariamente edita resolução suspendendo o dispositivo legal declarado inconstitucional pelo Pretório Excelso.

Entender de outra forma é o mesmo que negar vigência ao disposto no art. 52, inciso X, da Constituição Federal, contrariando o sistema constitucional adotado, ou seja o freios e contrapesos, o princípio constitucional democrático da Separação dos Poderes. É uma intromissão nas prerrogativas funcionais dos outros Poderes, uma ingerência que se configura ativismo judicial.

\section{b) O programa Mais Médicos}

O Programa Mais Médicos faz parte de uma política pública, instituída pela Medida Provisória nº 621, de 08 de julho de 2013, visando uma melhoria do atendimento aos usuários do Sistema Único de Saúde, prevendo investimentos em infraestrutura dos hospitais e levando mais médicos para regiões onde há escassez e ausência de profissionais.

O Senado Federal aprovou em 16/10/2013 o projeto de lei proveniente da medida provisória, permitindo a contratação de médicos estrangeiros e brasileiros formados no exterior para atuar em áreas pobres e remotas.

$\mathrm{Na}$ forma como foi aprovado pela Câmara dos Deputados, o texto do projeto transfere ao Ministério da Saúde a incumbência de fazer o registro dos médicos estrangeiros inscritos no programa. 
Um dos pontos mais polêmicos nos debates sobre a MP foi a necessidade de revalidação do diploma do médico estrangeiro. Segundo o texto aprovado, o estrangeiro não precisará revalidar o diploma nos três anos do programa. Os médicos estrangeiros somente poderão participar da prorrogação de três anos do Mais Médicos se integrarem "carreira médica específica", cuja definição depende de regulamentação em projeto de lei.

O registro dos médicos vindos do exterior será feito pelo Ministério da Saúde em substituição aos CRMs. Apenas a fiscalização do trabalho dos participantes do programa continuaria sendo feita pelos conselhos. Os médicos estrangeiros participantes do programa, porém, não poderão exercer a medicina fora das atividades do Mais Médicos.

O projeto do Executivo Federal foi questionado por meio de mandado de segurança da AMB (Associação Médica Brasileira) em 24/07/2013. Ainda não foi apreciada no Plenário do STF, mas a grande questão é acerca da legitimidade da Corte para discutir o mérito de políticas públicas. Se pode o Poder Judiciário interferir na instituição de programas públicos advindos do Executivo, e retificados pelo Legislativo, e quais são os argumentos que serão utilizados para tanto, se o STF será um Tribunal político, utilizando de argumentos políticos, para satisfazer a vontade de uma classe da população, por meio de argumentos discricionários.

O Ministro relator, Ricardo Lewandowski informou que o Judiciário não pode discutir o mérito de políticas públicas, especialmente no tocante ao reexame dos critérios de sua oportunidade e conveniência. Mas qual será o argumento sustentado pelos outros ministros, somente o tempo poderá demonstrar.

O fato é que, ao discutir e decidir acerca da conveniência de políticas públicas o STF está assumindo uma posição ativista, e mais uma vez, desrespeitando as atribuições constitucionais que lhe foram atribuídas.

\section{c) $O$ crime de evasão de divisas na Ação Penal 470}

A Ação Penal 470 diz respeito a um dos maiores e repercutidos julgamentos do STF, o famoso caso do "Mensalão". A atenção neste trabalho volta-se exclusivamente para a questão de o crime de evasão de divisas ser desconsiderado como um delito por meio de uma Circular do Banco Central. Ou seja, descriminalizou-se uma conduta por Circular, quando a Constituição exige para tanto, uma Lei Federal, editada com todos os tramites do processo legislativo, sendo a competência para tanto do Congresso Nacional.

A acusação era de que dois dos 37 réus da ação penal receberam R $\$ 11,2$ milhões do "valerioduto" e enviaram a maior parte do dinheiro (em torno de $\mathrm{R} \$ 10,8$ milhões) para uma conta do Bank of Boston em Miami. A maioria do STF entendeu que, no caso, não se configurou o crime de evasão de divisas, argumentando que uma circular do Banco Central prevê a comunicação de depósitos acima de US\$100 mil no exterior apenas no fim do ano fiscal, em 31 de dezembro. Assim, os denunciados não teriam praticado o crime de evasão de divisas.

Logo, para o STF, uma Circular do Banco Central, "descriminalizou” a conduta de evasão de divisas. O Pretório Excelso considerou válido um ato normativo de hierarquia inferior, sendo que deveria declara-lo inconstitucional frente a violação do art. 22 da CR/88.

Para Lênio Streck,

Diante de uma dúvida se uma Lei Federal pode perder validade em face de uma Circular administrativa, o Tribunal Constitucional deveria fundamentar a sua decisão, uma vez que, ao dar plena validade à Circular, deixou de lado uma Lei Federal, o que implica adentrar na esfera de competência legislativa, circunstância que demandaria a convocação da dicção dos artigos constitucionais que tratam da matéria ${ }^{54}$.

Mais, uma vez, o STF exerceu o ativismo judicial, violando os próprios preceitos da Constituição, utilizando argumentos políticos, e ingerindo na função de outro poder.

Assim, faz-se a diferenciação dos fenômenos de tal forma que delineia, por meio da prática de funda-

54 STRECK, Lenio Luiz. O fator Julia Roberts ou quando o Supremo Tribunal erra. Disponível em: < http://www.conjur.com. br/2012-out-25/senso-incomum-fator-julia-roberts-ou-quando-supremo-erra>. Acesso em: 06. set. 2014. 
mentação das decisões, o que se entende por judicialização da política e ativismo judicial.

\section{Conclusão}

Apesar dos limites conceituais entre judicialização e ativismo serem tênues, pode-se concluir da seguinte forma: judicializar é levar ao poder judiciário. Significa deduzir que o Poder Judiciário deve aplicar a ordem jurídica. Parte-se da premissa que determinadas questões que antes não eram tipicamente resolvidas pelo poder judiciário, agora o são. Não é um ato de vontade do judiciário, mas um conjunto de circunstâncias que fazerem com que o judiciário tenha essa atuação. A judicialização é um fato decorrente de alguma circunstância econômica, social, política ou jurídica.

A judicialização é uma consequência natural da abrangência da Constituição e de um Tribunal que está disposto a efetivá-la. Essa é uma questão de equilíbrio, uma tentativa de efetivação de direitos fundamentais e também de respeito à percepção do que os outros Poderes entendem a respeito da Constituição. Nem sempre o que é polêmico envolverá uma judicialização. Alguns casos polêmicos o poder judiciário confirmou o entendimento de outros Poderes.

A jurisdição constitucional não deve substituir a atuação do poder legislativo nem do poder executivo. Não deve haver uma presunção de que toda a atuação judicial, ainda quando envolva polêmica seja um caso de tensão entre os poderes.

Para Dworkin a judicialização pode melhorar o debate público na medida em que coloca esses fundamentos em jogo, em evidência. Os debates nos casos da ficha limpa, raposa cerra do sol, lei de biossegurança, fizeram com que os temas citados ganhassem maior repercussão quando estavam no STF, não quando passaram pelas decisões do Executivo e do Legislativo. Essa visão é que é benéfico para o debate público. Não é um desprestígio ao legislador, pelo contrário, o legislador continua a ter um papel central no debate público e é normal e desejável que o tenha, pois ele representa os diferentes segmentos sociais e com base nisso tem uma legitimidade natural para enfrentar os temas de interesse público sobre perspectiva múltipla.

A organização dos poderes não é definitiva, mas sim uma atividade em construção e, portanto, continuará sendo no tempo ajustada às demandas que os chama ao exercício. Existem teorias contemporâneas como a de Karl Loewenstein, que defende a tripartição das funções, baseada na dinâmica das políticas que devem ser adotadas, na implementação dessas políticas, e na execução das mesmas ${ }^{55}$, e a teoria de Bruce Ackerman, conhecida como "Parlamentarismo Limitado", composto por fatores limitadores do poder, um modelo de exercício de poder sob o controle interno mútuo, uma espécie de engrenagem constitucional, baseada no princípio democrático, no profissionalismo e na proteção de direitos fundamentais ${ }^{56}$.

O ativismo é uma postura deliberada do poder judiciário, é um termo mais carregado de valorações e complexidades práticas e teóricas. Ela foge do discurso jurídico para os avanços sociais. Há aqui um flerte com a corrente do realismo jurídico. O Ativismo judicial subvaloriza a política de tal forma que o jurídico assuma o posto do político, portanto, o ativismo decide fora do jurídico, sendo em grande parte populista, pois toda vez que o Judiciário decide para além dos princípios do direito, ele julga politicamente. Mas sabe-se que o judiciário não é preparado para essa decisão, não é de sua competência esse exercício, não é a especialidade. A legitimação legislativa depende do processo legislativo, o qual o Judiciário deve respeitar. A legitimidade executiva depende da atividade do Poder Executivo, é atividade política, não do Poder Judiciário.

55 Esse é o entendimento do autor em sua obra "Teoria da Constituição". LOEWENSTEIN, Karl. Teoria de la Constitución. 2. ed., Trad. Alfredo Gallego Anabitarte, Barcelona: Ariel, 1970.

56 ACKERMAN, B. The New Separation of Powers. Harvard Law Review, v. 113, n. 3, p. 633-729, 2000. Disponível em: <http:// www.palermo.edu/derecho/eventos/pdf/Ackerman_The_New_Separation_of_Powers_HLR.pdf>. Acesso em: 08 jan. 2015. 
Concluiu-se, portanto, que a questão pode ser entendida da seguinte maneira: o julgar politicamente e o julgar problemas que são afins à política são atividades distintas e que possibilitam pensar e verificar se, diante de uma Democracia Constitucional, os critérios normativos e de legitimidade fora cumpridos e as instituições públicas estão agindo legitimamente para com seus cidadãos.

\section{REFERÊNCIAS}

BARROSO, Luiz Roberto. Judicialização, ativismo judicial e legitimidade democrática. Revista de direito do Estado de Salvador, n. 13, jan./mar. 2009.

BARROSO, Luiz Roberto. Constituição, democracia e supremacia judicial: direito e política no Brasil contemporâneo. RFD - Revista da Faculdade de Direito - Uerj, v. 2, n. 21, jan./jun. 2012.

BEARD, Charles A. A Suprema Corte e a Constituição. Traduzido por Paulo Moreira da Silva. Rio de Janeiro: Forense, 1965.

BRASIL. Constituição (1988). Constituição da República Federativa do Brasil. Brasília: Senado, 1988.

BRASIL. Supremo Tribunal Federal. ADI 4277, j. 05.05.2011, voto do Min. Celso de Mello, p. 46. Disponível em: <http://www.stf.jus.br/portal/geral/verPdfPaginado.asp?id=400547\&tipo=TP\&descricao= ADI\%2F4277>. Acesso em: 25 set. 2014.

CITTADINO, Gisele. Judicialização da política, constitucionalismo democrático e separação de poderes. In: VIANNA, Luiz Werneck (Org.) A democracia e os três poderes no Brasil. Belo Horizonte: Editora UFMG, 2003.

DWORKIN, Ronald. Levando os direitos a sério. São Paulo: M. Fontes, 2002.

DWORKIN, Ronald. A justiça de toga. São Paulo: WMF M. Fontes, 2010.

DWORKIN, Ronald. O império do direito. Trad. Jefferson Luiz Camargo. 2. ed. São Paulo: M. Fontes, 2007.

DWORKIN, Ronald. Uma questão de princípios. Trad. Luís Carlos Borges. 2. ed. São Paulo: M. Fontes, 2005.

DWORKIN, Ronald. A raposa e o porco-espinbo: justiça e valor. Tradução Marcelo Brandão Cipolla. São Paulo: WNF M. Fontes, 2014.

FERNANDES, Bernardo Gonçalves; PEDRON, Flavio Barbosa Quinaud. O poder judiciário e(m) crise: reflexões de Teoria da Constituição e Teoria Geral do Processo sobre o acesso à justiça e as recentes reformas do poder judiciário à luz de Ronald Dworkin, Klaus Günther e Jürgen Habermas. Rio de janeiro: Lumen Juris, 2008.

HART, H. L. A. et al. O conceito de direito. São Paulo: WMF M. Fontes, 2009.

LAGES, Cíntia Garabini. A proposta de Ronald Dworkin em o império do direito. Revista da Faculdade Mineira de Direito, Belo Horizonte, v. 4, n. 7/8, jan./jun., 2001.

MARQUES, Gabriel Lima; LOIS, Cecília Caballero. Reforma política e diálogos institucionais: novas possibilidades de superação da judicialização da política no Brasil. In: XXI ENCONTRO NACIONAL DO CONPEDI, 21. 2012. Uberlândia, MG. Anais... Florianópolis: Fundação Boiteux, 2012. p. 14740-14763.

MENDES, Gilmar Ferreira. Jurisdição constitucional: o controle abstrato de normas no Brasil e na Alemanha. 5. ed. São Paulo: Saraiva, 2005.

MÜLLER, Friedrich. Quem é o povo?: a questão fundamental de democracia. 3. ed. São Paulo: Max Limonad, 2003. 
NUNES, Dierle José Coelho. Processo jurisdicional democrático: uma análise crítica das reformas processuais. Curitiba: Juruá, 2008.

OLIVEIRA, Marcelo Andrade Cattoni de; BAHIA, Alexandre Melo Franco; NUNES, Dierle. Controle de constitucionalidade é jurídico, não político. 30 de abril de 2013. Disponível em: < http:/ / www.conjur.com.br/2013abr-30/sistema-controle-constitucionalidade-judicial-nao-politico>. Acesso em: 06 out 2013.

PEDRON, Flávio Quinaud. A proposta de Ronald Dworkin para uma interpretação construtiva do direito. Revista CEJ, Brasilia, Ano XIII, n. 47, p. 127-137, out./dez. 2009.

PEDRON, Flavio Barbosa Quinaud. Mutação constitucional na crise do positivismo jurídico: história e crítica do conceito no marco da teoria do direito como integridade. Belo Horizonte: Arraes, 2012.

PAIXÃO, Cristiano; BIGLIAZZI, Renato. História constitucional inglesa e norte-americana: do surgimento à estabilização da forma constitucional. Brasília: Finatec, 2011.

POGREBINSCHI, Thamy. Judicialização ou representação?: política, direito e democracia no Brasil. Rio de Janeiro: Elsevier, 2011.

RAMOS, Elival da Silva. Ativismo judicial: parâmetros dogmáticos. São Paulo: Saraiva, 2010.

RODRIGUES, Leda Boechat. História do Supremo Tribunal Federal. Rio de Janeiro: Civilização Brasileira, 1991.

SILVA, Diogo Bacha e Silva. Ativismo no controle de constitucionalidade: a transcendência dos motivos determinantes e a (I)legítima apropriação do discurso de justificação pelo Supremo Tribunal Federal. Belo Horizonte: Arraes, 2013.

STRECK, Lenio Luis; MORAIS, José Luis Bolzan de. Ciência politica e teoria do Estado. 6. ed. Porto Alegre: Livraria do Advogado, 2008.

STRECK, Lenio Luiz. Emenda dos precatórios, STF pode legislar? Não! Disponível em: < http://www.conjur. com.br/2013-out-31/senso-incomum-emenda-precatorios-stf-legislar-nao2>. Acesso em: 06 nov. 2013.

STRECK, Lenio Luiz. O fator Julia Roberts ou quando o Supremo Tribunal erra. Disponível em: < http:// www.conjur.com.br/2012-out-25/senso-incomum-fator-julia-roberts-ou-quando-supremo-erra>. Acesso em: 06 set. 2014.

STRECK, Lenio Luiz. A atualidade do debate da crise paradigmática do direito e a resistência positivista ao neoconstitucionalismo. Revista do Instituto de Hermenêutica Jurídica, Porto Alegre, n. 4, p. 223-262, 2006.

STRECK, Lenio Luiz. Prefácio. In: TASSINARI, Clarissa. Jurisdição e ativismo judicial: limites da atuação do judiciário. Porto Alegre: Livraria do Advogado, 2013.

STRECK, Lenio Luiz. Verdade e consenso: constituição, hermenêutica e teorias discursivas da possibilidade à necessidade de respostas corretas em direito. 3. ed. Rio de Janeiro: Lumen Juris, 2009.

TASSINARI, Clarissa. Jurisdição e ativismo judicial: limites da atuação do judiciário. Porto Alegre: Livraria do Advogado, 2013.

TATE, N.; VALLINDER. T. The global expansion of judicial power: the judicialization of politics. In: The global expansion of judicial power. New York: New York University Press, 1995.

THEODORO JÚNIOR, Humberto; NUNES, Dierle José Coelho; BAHIA, Alexandre Gustavo Melo Franco. Breves considerações sobre a politização do Judiciário e sobre o panorama de aplicação no direito brasileiro: análise da convergência entre o civil law e o common law e dos problemas da padronização decisória. Revista de Processo, São Paulo, v. 35, n. 189 , p. 09-52, nov. 2010.

VERÍSSIMO, Marcus Paulo. A Constituição de 1988, vinte anos depois: suprema corte e ativismo judicial “à brasileira”. Revista Direito GV, São Paulo, v. 4, n. 2, p. 407-440, jul./dez. 2008. 
VIANNA, Luiz Werneck et al. A judicialização da política e das relações sociais no Brasil. Rio de Janeiro: Renavan, 1999.

VIEIRA, Oscar Vilhena. Supremocracia. Rev. direito GV [online]. v. 4, n. 2, p. 441-463, 2008.

VIEIRA, Oscar Vilhena. Supremo Tribunal Federal: jurisprudência política. São Paulo: Revista dos Tribunais, 1994. 
Para publicar na revista Brasileira de Políticas Públicas, acesse o endereço eletrônico www.rbpp.uniceub.br

Observe as normas de publicação, para facilitar e agilizar o trabalho de edição. 